\title{
Environmental Health And Public Safety Through Fecal Sludge Management And Socio-Economic Analysis
}

\author{
Ratu Ayu Dewi Sartika \\ \{ayu_fkm_ui@yahoo.com\} \\ Center for Epidemiological Research \& Surveillance, Public Health Nutrition, \\ Universitas Indonesia, Depok, West Java, Indonesia
}

\begin{abstract}
Lack of fecal sludge management systems (FSM) at the household level is a global problem and an inhibitor to sustainable development. FSM includes the storage, collection, transport, treatment, safe end use, or disposal of fecal sludge. The majority of people in developing countries rely on onsite sanitation which generates fecal sludge. Fecal sludge is often allowed to accumulate in the environment. Fecal sludge is a growing challenge, generating significant risks to the environment and public health. This paper evaluates FSM at the household level in the collection and emptying of the Indonesian provinces of Sumatera Barat and Lampung. The study quantifies safe environment level of FSM at the household level by collecting data via socioeconomic demographics of the wealth index, household member, ownership, and distance to body water. The study reveals the majority of households in both Provinces do not have proper FSM in collection and emptying. Limited FSM disposal services result in a fraction of the fecal sludge being disposed in a treatment plant. This poses a major challenge for Indonesia to achieve universal sanitation access.
\end{abstract}

Keywords: Fecal sludge management, on-site sanitation, universal access to sanitation, sustainable development.

\section{Introduction}

Globally, 2.7 billion people rely on on-site sanitation, but many lack the means to manage fecal sludge that accumulates over time in septage or pit latrines, which can have significant health and environmental implications. As a result, faecal sludge management (FSM) has become a key component of providing universal sanitation access. Untreated fecal sludge can contaminate the environment and generate risk to public health (World Bank, 2016). Disposal of fecal sludge to an open drain will increase pathogens into the environment and can cause diarrhoea. Inadequate sanitation is estimated to cause the 280.000 diarrhoeal deaths per year (Pruss-Ustun et al., 2014). This is a serious risk to public health such as chronic

Diarrhoea (Dangour et al,. 2013. Lin et al., 2013), economic lost due to stunting and reduced cognitive capacity [1]. Diarrhoea was estimated to have killed 2.2 million people every year (WHO, 2000). Faecal sludge removed from all kind of on-site sanitation such as septic tanks, latrines, toilets, and pit latrines (Sandec, 2002). Mostly faecal sludge is not 
managed properly with a lack of safe emptying, no treatment plants and disposal directly to the environment. [2]. Fecal sludge needs to be emptied periodically. If the sludge is not managed properly it can have a risk impact on the environment and public health [3]. Fecal sludge contains a large number of microorganisms. These microorganisms are pathogenic and untreated fecal can cause significant health risks to humans, either through direct contact or exposure. Such wastes need to be managed so that the adverse effects are minimised to protect the environment and human health. Fecal sludge there for needs to be managed to a more hygienic and adequate level based on the proper treatment options. The exposure path for each sludge is very different for sludge discharged into the environment, sludge used in agriculture, or sludge that is reused as a fuel source [2]. The sludge management therefore needs to be safely managed through the phases of storage, collection, emptying, transportation, treatment, reuse and final disposal. [2]. Sludge treatment is carried out as one of the technical solutions for the management of safe sanitation services from desludging to the waste treatment plant [4].The majority of the population of urban areas in Indonesia use onsite sanitation facilities while services for sludge management are still limited in various cities (WSP, 2013). Nearly $83 \%$ of feces from onsite sanitation, such as septic tanks contaminates the environment. Only $17 \%$ of households emptied their septic tanks (WSP, 2013) while Indonesia has set a 100\% target for universal access to sanitation in 2019 (Bapenas, 2015). Fecal sludge management is an effort to support this target (World Bank, 2017).

Basic Health Research (Riskesdas, 2013) shows 58.9\% of households in Indonesia have access to a septic tank. Many households do final disposal of fecal directly into the environment such as to the beach, river, lake, sea, pond, rice field, land or garden. Safely managing the fecal sludge is an essential service that is often neglected. (Strande et al, 2015). Safe FSM disposal in Indonesia is critical in order to achieve $100 \%$ of the target towards universal sanitation access by 2019. Study in South Lampung province showed that collection and emptying FSM were not safe to the environment. Access to proper sanitation in Lampung is only $45 \%$ (World Bank, 2014). Other study on WASH in Lampung shows that only $18 \%$ of households have a proper collection for fecal and safe emptying. As many as $78.2 \%$ of households in Tanjung Sari sub district, South Lampung does not have the facilities to collect fecal and have not carried out safe toilet drainage. This shows the potential for contamination of feces into the environment including water and soil bodies (SNV, 2016).

Indonesian Health Profile from the 2016 Central Bureau of Statistics in West Sumatra shows that there were only $53.61 \%$ of households have final disposal of feces into septic tanks and a very low percentage $(0.76 \%)$ was processed through a Wastewater Management System (SPAL). 32.28\% of fecal waste is discharged into ponds, rice fields, rivers, lakes, seas and $2.32 \%$ is discharged to the beach or field, $11.03 \%$ to the land and the soil. Meanwhile in Lampung, $59.60 \%$ of households end stool disposal is connected to septic tanks, $0.04 \%$ is discharged to SPAL, and $8.25 \%$ is discharged into ponds or rice fields in rivers or lakes or sea. $30.39 \%$ of fecal waste is discharged to the soil and beach pits, fields, and $1.72 \%$ into gardens. These statistics reveal that many households do not meet the conditions of safe environmental sludge management. Waste from sewage sludge has the potential to pollute ground and surface water which is harmful to human health.

This research was conducted to analyze safety level of Fecal Sludge Management (FSM) for the environment by economic and social demographic of households in the West Sumatra and Lampung provinces. The level of FSM safety is segregated and the correlation is examined according to household economic and social demographic variables which include the wealth index (quantiles), gender of the household head, occupation of household head, the number of family members, house ownership status, and the location of the household to the water body. There are still many households that do not meet the conditions of safe fecal 
sludge management for the environment even though safe management can prevent pathogenic contamination into the environment which has a serious impacts on human health. This problem is caused by improper collection or collection of feces and desludging of septic tanks. Fecal wastes have the potential to contaminate ground water and surface water that are harmful to human health, because fecal waste contains coli bacteria that can cause diarrhea. Solid and liquid feces contain pathogenic bacteria from human feces. If they are not treated, wastewater can transmit the disease to humans, especially through water (waterborne disease).

The main objective of this study is to present an analysis of the level of safety of sludge management at the household level in West Sumatra and Lampung. The specific objectives of this study are to: (1) Analyze the level of safety of household sludge management in the environment; (2) Analyzing the level of safety of household sludge management in the environment according to household economic and social demographics (wealth quantiles, gender of head of household, occupation of head of household, number of family members, house ownership status, location of household to water body); (3) Analyzing the relationship between the level of security of household sludge management in the environment with the household's socio-demographic economy (level of wealth index, status of house ownership).

\section{Method}

The approach in this study uses quantitative data analysis. The study was carried out in West Sumatra and Lampung. Quantitative data collection was carried out from household survey data collection. The variables of this study were the level of safety of sludge management on the environment and the economic and social level of household demographics. In this study an assessment of the level of sludge management at the household level was carried out in the collection and desludging of sludge. The level of fecal sludge safety is analyzed starting from the management level with the lowest (score 0) to an acceptable safe management level (score 4). The safety level is then analyzed according to the economic and social characteristics of household. Household economic and social variables are then assessed for their level of association at the level of safety of the sludge management introduction into the environment.

The following research hypothesis used in this study:

1. Households with upper wealth quantile tend to have a higher level of safety in managing fecal sludge in to environment

2. House ownership status tend to have a higher level of safety in managing fecal sludge in to environment.

\section{Results And Discussion}

Table 1 Distribution of Respondent in two provinces

\begin{tabular}{lcccc}
\hline Province & District & Subdistrict & Number of Respondent & Percent \\
\hline Lampung & Pringsewu & Pagelaran Utara & 383 & 12.3 \\
Lampung & Pringsewu & Ambarawa & 364 & 11.7 \\
Lampung & Lampung Selatan & Rajabasa & 451 & 14.5 \\
Lampung & Lampung Selatan & Sidomulyo & 409 & 13.2 \\
West Sumatera & Padang Pariaman & Enam Lingkung & 368 & 11.8 \\
West Sumatera & Padang Pariaman & Ulakan Tapakis & 399 & 12.8 \\
West Sumatera & Sijunjung & Lubuk Tarok & 339 & 10.9 \\
\hline
\end{tabular}




West Sumatera Sijunjung Sumpur Kudus
Total

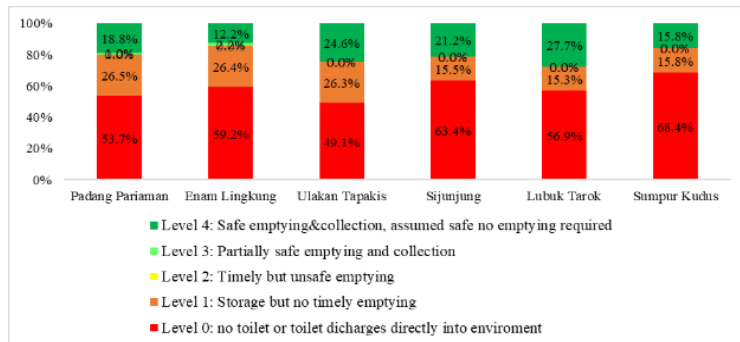

Figure 1. FSM emptying \& collection in West Sumatera

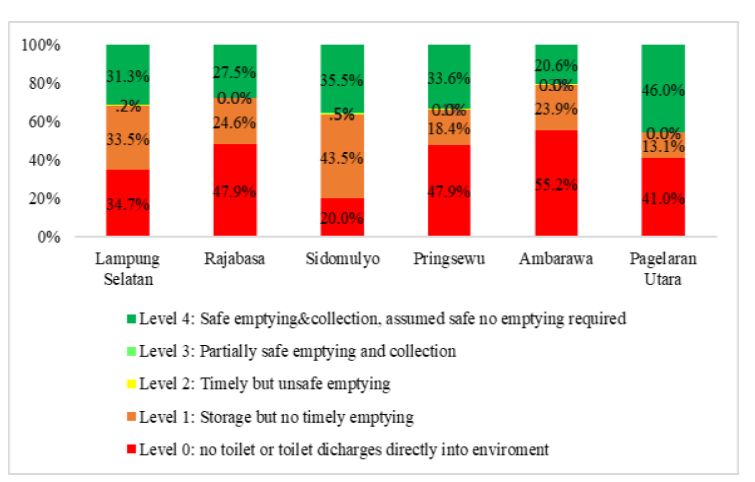

Figure 2. FSM emptying \& collection in Lampung

The variance proportion of the safety level of sludge management introduced into the environment is most prominent among household economic status in West Sumatera based on wealth quantiles (Figure 3). The proportion of households that are declining in wealth are the greater proportion who have not yet carried out safe management of introducing fecal matter 
appropriately into the environment. Conversely, wealthier families tend to use a safe level of sludge management into the environment.

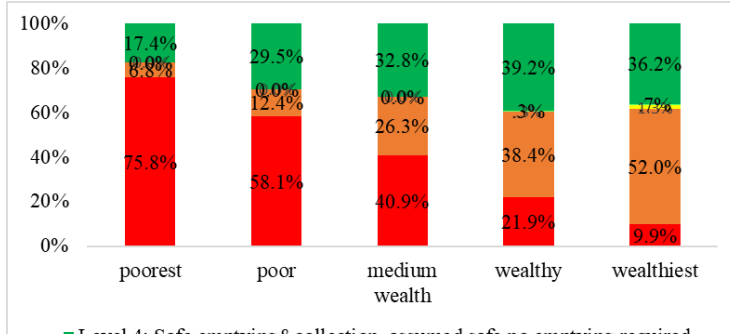

- Level 4: Safe emptying\&collection, assumed safe no emptying required

Level 3: Partially safe emptying and collection

Level 2: Timely but unsafe emptying

- Level 1: Storage but no timely emptying

- Level 0 : no toilet or toilet dicharges directly into enviroment

Figure 3. Collection and Emptying of fecal sludge by household wealth index in Lampung

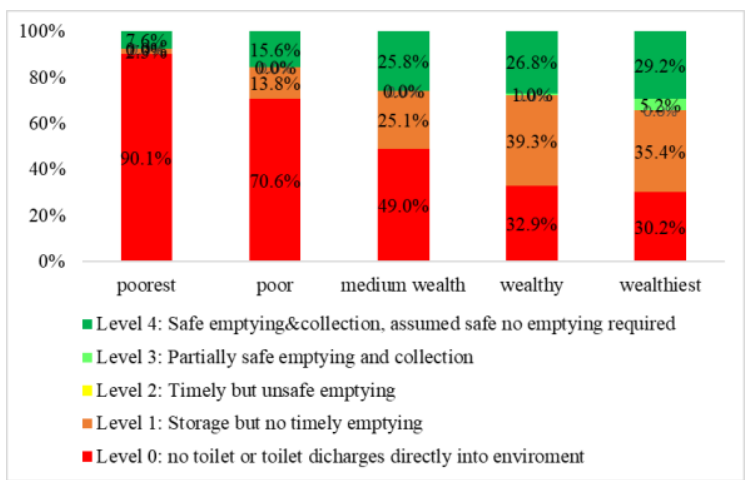

Figure 4. Collection and Emptying of fecal sludge by household wealth index in West Sumatera

Collection and Emptying of fecal sludge by house ownership is shown in figure 5 and 6 in West Sumatera and Lampung. It shows that households that own the house tend to manage sludge not yet safe (Figure 5 and 6). Households that have their own house tend to lead to safer fecal management than those who do not own their own homes (lower level).

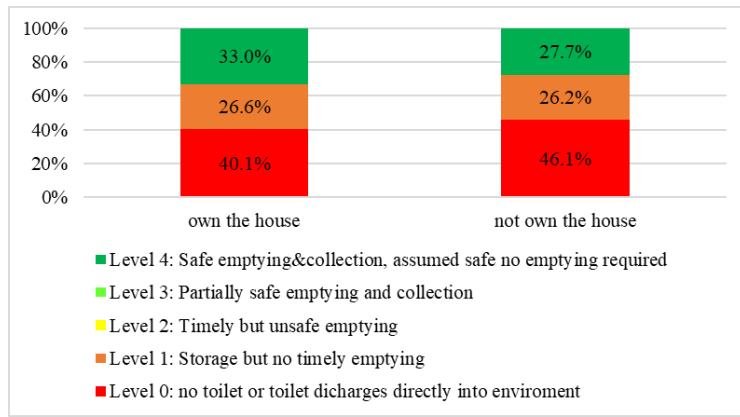

Figure 5. Collection and Emptying of fecal sludge by house ownership in Lampung 


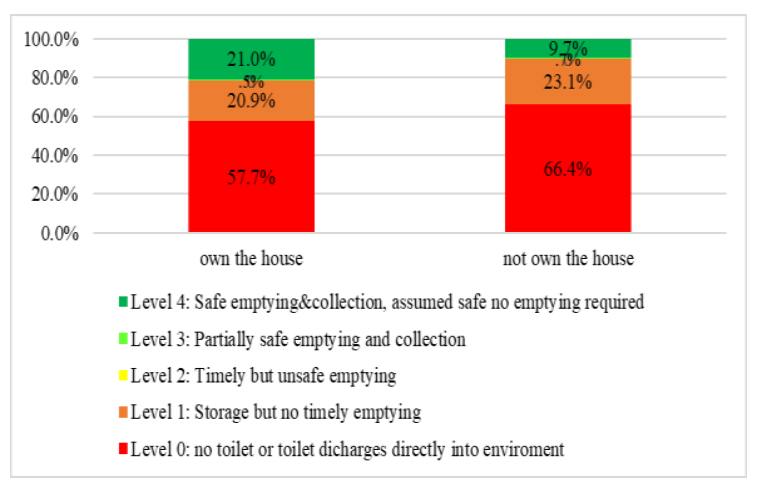

Figure 6. Collection and Emptying of fecal sludge by house ownership in Lampung

\section{Conclusion}

The majority households in West Sumatera have no toilet or they have a toilet but discharge fecal sludge directly into the environment. Only a small proportion of household have safe emptying and collection in West Sumatera and Lampung. The proportion of households implementing safe fecal sludge management in West Sumatera has a higher difference variance in emptying and collection. The safety level of sludge management into the environment is higher in wealthier families both in West Sumatera and Lampung. West Sumatera has a higher difference variance in the safety level. Households that with a higher level of ownership tend to lead to safer fecal management than those who do not own their own homes.

\section{Acknowledgements}

If any, should be placed before the references section without numbering.

\section{References}

[1] D. Spears, A. Ghosh, and O. Cumming, "Open Defecation and Childhood Stunting in India: An Ecological Analysis of New Data from 112 Districts," PLoS One, vol. 8, no. 9, pp. 1-9, 2013.

[2] L. Strande, M. Ronteltap, and D. Brdjanovic, Fecal Sludge Management: Systems Approach for Implementation and Operation. London: IWA Publishing, 2014.

[3] F. Klingel, "Swiss Agency for Development and Cooperation Nam Dinh Urban Development Project Septage Management Study,” no. January, 2017.

[4] M. O'Riordan, WRC PROJECT 1745 Management of sludge accumulation in VIP latrines. kwazulu-natal: partners in development, 2009. 